When going too far is going just far enough: Appropriation, parody and adaptation in Lydia Davis'short stories

\title{
Lynn Blin
}

\section{CpenEdition}

\section{Journals}

Electronic version

URL: http://journals.openedition.org/esa/3338

DOI: $10.4000 /$ esa.3338

ISSN: 2650-2623

\section{Publisher}

Société de stylistique anglaise

\section{Printed version}

Date of publication: 31 December 2018

Number of pages: 141-160

ISBN: 978-2-36442-083-0

ISSN: 2116-1747

Electronic reference

Lynn Blin, « When going too far is going just far enough: Appropriation, parody and adaptation in Lydia Davis'short stories », Études de stylistique anglaise [Online], 13 | 2018, Online since 20 March 2019, connection on 20 March 2020. URL : http://journals.openedition.org/esa/3338 ; DOI : https://doi.org/ 10.4000/esa.3338 


\title{
When going too far is going just far enough: Appropriation, parody and adaptation in Lydia Davis'short stories
}

\author{
Lynn BLIN \\ Univ Paul Valéry Montpellier 3, EMMA (EA 741) \\ F34000, Montpellier, France
}

In her 2015 collection Can't and Won't, Lydia Davis incorporated 14 stories that were extracted from Gustave Flaubert's correspondence sent to his mistress Louise Colet in 1853-1854 while Flaubert was writing Madame Bovary. Ten of these extracts were first published in the Paris Review with the title "Ten Stories from Flaubert" (Davis 2010). The date of publication in the Paris Review corresponded to the date of publication of Davis' translation of Madame Bovary. Jonathan Evans surmises that the reader might probably have assumed that they were excerpts from Madame Bovary itself (Evans 2017, 106). The stories were later included in Can't and Won't along with four others, but in the collection, Davis includes in the acknowledgements an explanation of their provenance, adding:

\footnotetext{
My aim was to leave Flaubert's language as little changed as possible only shaping the excerpt enough to create a balanced story, though I took whatever liberties I thought were necessary (in one case, for instance, combining material from two letters so that the two related stories were turned into one; in another case, adding some factual material to a story to give more background to a character). (Davis 2015, 289)
}

Evans, who has worked extensively on the link between Davis the translator and Davis the writer, upholds Davis' assessment and concludes: "In the end, there are a number of minor changes made to the texts in translation, but they still remain recognizable in relation to their sources" 
WHEN GOING TOO FAR IS GOING JUST FAR ENOUGH:

APPROPRIATION, PARODY AND ADAPTATION IN LYDIA DAVIS'SHORT STORIES

(Evans 2017, 106). If the sources are indeed recognizable, a closer examination will reveal modifications that cannot be considered as "simply minor". This paper aims to examine how Davis adapted these extracts into short stories and the extent of some of the modifications. In Blin (2017), I examined how the voice of the translator is omnipresent in her short stories. The specific attention Davis pays to language illustrates how, very often, she is dealing with grammatical and stylistic questions that are at the heart of translation. This paper will further examine this dimension to demonstrate how these letters from Flaubert correspond to a general coherence, not only in Can't and Won't, but in Davis' works as a whole. Translation, translators, correspondence and adaptation are a constant throughout her works. Like her literary model Samuel Beckett, Davis' stories confirm the instability of meaning and, like the works of Maurice Blanchot, which Davis translated, they are a constant reminder of how language cannot be trusted. Though a comparison with Flaubert might at first seem improbable, Davis' attention to word choice and word order will prove to be as demanding as Flaubert's, and in capturing the spirit of the nineteenth century writer she has managed not only to resurrect Flaubert, but by making him co-author, she has also transformed him into a twentyfirst century writer.

\section{Davis' invitation to pay attention to grammar}

In his introduction to Lydia Davis's Collected Stories Sir Christopher Ricks quotes T.S. Eliot:

Of course one can 'go too far', and except in directions in which we can go too far there is no interest in going at all; and only those who will go too far can possibly find out just how far one can go. (Eliot in Ricks 2013, xxii)

The predominant, often quirky narrative voice in her very short stories (some of them less than 10 words long) ${ }^{1}$, given to musings on

\footnotetext{
Davis considers herself a short story writer. Though she fully acknowledges the experimental aspect of her work she strongly refutes the classification of her writing as poetry. She explains: "Leaving aside whether or not some of my stories may be poetry, the problem of how to write an actual poem with line breaks still seems very interesting and mysterious. The truth is, I don't know how to do it" (McCaffery 1996, 76). As for the experimental aspect of her writing, it is important to note that it is not experimentation for the sake of experimentation. Ricks explains: "There are many kinds of vigilance in the art
} 
aspects of everyday life that flash through our minds which the narrator unrelentingly works to the bone, is, like that of the translator, in quest of interpretation. To the reader discovering her for the first time, her stories may seem to be no more than nonsense, and Davis might seem indeed to be taking her quest for concision too far indeed. Take for example the following:

\section{They Take Turns Using a Word They Like}

"It's extraordinary," says one woman.

"It is extraordinary," says the other. (Davis 2013, 403)

It's/It is extraordinary could be classified as an extraposition construction which allows end focus and end-weight to the real grammatical subject which is ellided in the story: e.g. "It's extraordinary," says one woman. "that he would go to jail for his wife."

Since, the pronoun it here has only an implicit unidentified referent, the source of their wonderment is left to the imagination of the reader, but this can hardly be the only point of the story. The reader might be called upon to reflect on the grammatical diversity of "it", as well as the aforementioned vagueness. It can have as referent a material object, or a whole utterance. It can be cataphoric, announcing something that has not already been mentioned, which is what the reader might expect when he/she reads a first sentence in a story. But in this story, there is no completive clause that follows.

In this structure, the real notional subject of the sentence, e.g. that he would go to jail for his wife, is rejected at the end of the sentence for questions of end-focus and end-weight (the more syntactically complex clause is traditionally placed at the end of the utterance). It can also be anaphoric, but the absence of referent annuls this function of the pronoun as well.

What predominates in this story is therefore the repeated adjective extraordinary. But do they actually say the same word?

of Lydia Davis: vigilance as how to realize things down to the very word or syllable, alive not least in the punctuation [...], vigilance when it comes to her own experimentalism, lest she become prisoner to her own new-fashioned way of doing things; vigilance as to there being no room for repeating what really matters" (Ricks xx). 
WHEN GOING TOO FAR IS GOING JUST FAR ENOUGH:

APPROPRIATION, PARODY AND ADAPTATION IN LYDIA DAVIS'SHORT STORIES

The expansion of the clitic it's into it is triggers a modification in the emphasis pattern on the sentence. In order to express agreement and echo/or reinforce the emphasis, the full verbal form has to be used. The tonic emphasis is subsequently switched onto the verb instead of the default last word. The story read aloud will have the following intonation scheme:

“It's EXTRAORDINARY," says one woman.

"It IS extraordinary," says the other.

In American English, the word can be pronounced in six different ways:

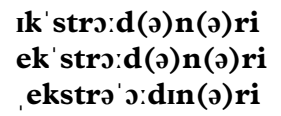

Since it is the adjective that has been given prominence in the narrative, the reader can therefore be called upon to pay extra attention to the word itself. We note that even if it was the pronunciation ,ekstrə'o:dınəri in which each syllable was fully pronounced, we might notice that strangely enough extra ordinary does not mean more ordinary than ordinary; it does not mean exceptionally ordinary, but exceptional, unusual, remarkable. This is because EXTRAORDINARY here is not a compound word composed of the adverb EXTRA and the adjective ORDINARY, but of the prefix EXTRA from the Latin which means outside, beyond. In this case "extra" would be autonomous as in "extra kind".

What upon a first reading appears to be repetition turns out to be more complex. The two women may be saying the same word, but the rules of intonation in English mean they do not say it in the same way. The story may also be a comment on the fact that overusing a word like extraordinary might suggest that when it is used too often it gradually loses the impact of its meaning. And the omission of the referent for it would thus confirm this interpretation ${ }^{2}$.

2 I have made up a possible completive to this sentence, but as one of the anonymous reviewers of this article, whom I would like to thank, suggested, the completive could be the very fact that they take turns using a word they like is extraordinary. The reviewer also suggested a third interpretation: "They take turns using $\mathbf{A}$ word they like. The indefinite 


\section{Translators, Translating, and Invention}

Before we examine more closely Davis' adaptation of Flaubert's correspondence, it is relevant to our analysis to also investigate the ways she has adapted other authors' works into her fiction. Appropriation and adaptation of the works of others is a constant throughout her oeuvre, as is the theme of translation itself. Letters in various forms also crop up with a regularity that is more than coincidental. Additionally, in many of her stories, the main character and/or narrator is a translator. In "Kafka Cooks Dinner" (Davis 2013, 509-519) for example, Davis adopts Kafka's style and tells a story about Kafka preparing a dinner for a friend, Milena. Evans (135) explains that there was a real Milena in Kafka's life, who was his Czech translator, and the story is a pastiche of Kafka's style with the preparation for the dinner taking on apocalyptic dimensions. For example:

As I plan this meal, I feel like Napoleon would have felt while designing the Russian campaign if he had known exactly what the outcome would be. (Davis 2007, 9)

The story appears in the collection Varieties of Disturbance and in the acknowledgements, it is explained that some of the material was taken from Letters to Milena by Franz Kafka. But there are no precisions on how the letters are used. Evans confirms that in Kafka's letters there is a similar remark, relating to travel plans:

I feel like Napoleon must have felt if, while at the same time he was designing the Russian campaign, he had known exactly what the outcome would be. (Kafka 1990, 24 in Evans, 135)

Evans goes on to explain:

[...] one of the effects of the pastiche of Kafka's writing style is that the whole text appears as if it could be a citation. The text is received as if it were a montage, and the reader cannot, without recourse to the source text, decide what is original to the story and what is taken from the source text. (135)

article $\mathbf{A}$ preconstructs the existence of $\mathbf{A}$ word they like. A word they like । the word > IT is extraordinary. IT would then refer back to a word they like. 
WHEN GOING TOO FAR IS GOING JUST FAR ENOUGH:

APPROPRIATION, PARODY AND ADAPTATION IN LYDIA DAVIS'SHORT STORIES

Evans draws an interesting comparison with the visual arts:

In the visual arts, there are some works that operate on a similar principle: they appear, on first viewing, to be found objects, but after some study turn out to be fabricated by the artist. An example would be Jeff Koons' Popeye Series (2002 - ongoing), where what appear to be inflatable swimming pool toys, for example a giant lobster, turns out to be made from aluminum and painted to resemble rubber toys. [...] The Popeye Series plays with the expectations of the viewer, who has come to accept the use of found objects and other heterogeneous materials in modern art, and so accepts the 'rubber toys' at face value, at least initially. (135-136)

Thus it is with Davis and Kafka - what at first we might imagine to be extracts from Kafka's various letters also plays with the expectations of the reader. What we might initially think are citations from Kafka turn out to be partially so, but also inventions on the part of Davis herself.

In another story, Davis adapts Beckett's Worstword Ho into her own story, "Southward Bound, Reads Worstword Ho" (Davis 2013, 571574). Beckett's style is appropriated, the story itself is appropriated, but there is also a certain amount of invention on the part of Davis.

In another story, "The Walk" (Davis 2013, 575-587), a translator and the keynote speaker at a conference in Oxford on the translations of Proust walk around the town together. During his talk, the speaker had explained why an earlier translation of Swann's Way was superior to her own. Davis includes an extract of the translation he refers to, that of C.K. Scott Moncrief, and her own translation of the work.

It is yet another translator who is the main character in her story "Letter" (Davis, 2013, 40-46), where a woman who works as a translator receives a letter from her former lover in the form of a hand-written smudged French poem signed with her lover's name, and she is required to translate and interpret not only the words on the page, but very often the order of words, the punctuation, the sound of words.

\section{Lydia Davis and Martin Buber}

One of the most interesting stories with regards to Davis' penchant for appropriation is entitled "Once a Very Stupid Man" where Davis adapts a translation of a Hassidic fable, The Way of Man by Martin Buber into her short story, slightly modifying it to make it better suited to the dilemma of the protagonist, an unnamed woman who habitually cannot 
find her clothes in the morning when she must get dressed, a dilemma she shares with the "stupid man" in the fable. The provenance of the fable is acknowledged in the preface of the collection. In the following analysis I will demonstrate how the exchanging of one grammatical form for another enables a shift in interpretation.

Evans compares the two versions of the tale found below. Davis' modifications are in bold type:

There was once a man who was very stupid. When he got up in the morning it was so hard for him to find his clothes that at night he almost hesitated to go to bed for thinking of the trouble he would have on waking. One evening he finally made a great effort, took paper and pencil and as he undressed noted down exactly where he put everything he had on. The next morning, very well pleased with himself, he took the slip of paper in his hand and read: 'cap' - there it was, he set it on his head; 'pants' there they lay, he got into them; and so it went until he was fully dressed. "That's all very well, but now where am I myself?" he asked in great consternation "Where in the world am I?" He looked and looked, but it was a vain search; he could not find himself. 'And that is how it is with us,' said the rabbi. (Buber 2002, 22-23, in Evans, 132)

"'There was once a man who was very stupid. When he got up in the morning it was so hard for him to find his clothes that at night he almost hesitated to go to bed for thinking of the trouble he would have on waking. One evening he took paper and pencil and with great effort, as he undressed, noted down exactly where he put everything he had on. The next morning, well pleased with himself, he took the slip of paper in his hand and read: 'cap' - there it was, he set it on his head; 'pants' - there they lay, he got into them; and so it went until he was fully dressed. But now he was overcome by consternation, and he said to himself: "This is all very well, I have found my clothes and I am dressed, but where am I myself? Where am I?" And he looked and looked, but it was a vain search; he could not find himself. And that is how it is with us, said the rabbi"”. (Davis 1986, "Once a Stupid Man" in Break it Down in Evans 132)

Upon a first reading, there does not seem to be much difference. However, whereas the man in the Hassidic tale suffers an existential identity crisis, Davis' modification enables the expression of the crisis as a prolepsis to the woman's mental breakdown which will be highlighted at the end of her story. In the original fable, Buber clearly states that the question answered is Where is man in the world ${ }^{3}$. Also, since it is to be

\footnotetext{
Buber's fable is available on the WEB. Here is the excerpt:

"How are we to understand that God, the all-knowing said to Adam: 'Where art thou?",
} 
WHEN GOING TOO FAR IS GOING JUST FAR ENOUGH:

APPROPRIATION, PARODY AND ADAPTATION IN LYDIA DAVIS'SHORT STORIES

read as a parable, Buber clearly states the lesson to be learnt i.e. "he must find his own self, not the trivial ego of the egotistical individual" (Buber 2015).

In both the Buber text and the Davis version of it, the feeling of well-being procured by finding the clothes is deflated by a sense of greater personal loss. The existential question of the stupid man in Buber's tale is expressed in two direct quotes the introductory clause of which "he asked in great consternation" is in the active voice and modified by an adverbial manner phrase, "in great consternation":

"That's all very well, but now where am I myself?" he asked in great consternation.

"Where in the world am I?" He looked and looked...

In Davis' modification the two self-interrogatives are stretched out into a single direct quote; the deictic pronoun that in Buber's tale, becomes this; there is an addition of the coordinate conjunction but at the beginning of a sentence; an italicization of the pronoun $\mathbf{I}$ and the addition of the coordinate conjunction and, also at the beginning of a sentence. The consternation of the man is expressed by the passive voice:

But now he was overcome by consternation and he said to himself: "This is all very well, I have found my clothes and I am dressed, but where am I myself? Where am $I$ ?" And he looked and looked....

Where am I in the world is omitted in Davis' version, because the woman character in her story is not interested in her place in the world, as her mental state has deteriorated to a point that does not allow her the comparable luxury of existential musings. Davis chooses italics on the final pronoun $I$. This italicization is necessary in writing for the pronoun to receive a tonic accent. The rules of intonation make the default tonic word accent fall on AM unless otherwise specified.

In the passive voice construction, the real grammatical subject, which is the agent, is either left unmentioned because it is obvious, or, as is the case in our example above, placed at the end of the sentence. In Davis'

"Do you believe," answered the rabbi, "that the Scriptures are eternal and that every era, every generation and every man is included in them?" "I believe this," said the other.

"Well then," said the zaddik (so the leaders of the Hasidic communities are called), "in every era, God calls to every man: 'Where are you in your world?"' (Buber 2015). 
modification, from being an agentive subject experiencing consternation, the man is turned into a patient subject overcome by consternation. Hence, in this passage, in Davis' version of the fable, the grammatical form can be interpreted to express the loss of the real subjecthood of the man. As Evans points out:

Both characters can be seen to suffer a breakdown of identity, but the man in the parable loses himself, whereas the female character loses the sense of her own boundaries (just as the quotation problematises the boundaries of the text). (Evans 133)

The passive voice enables an added prominence to the real grammatical subject, consternation, which, according to the rules of intonation, benefits from default end-focusing ${ }^{4}$. As Davis' story progresses, the woman increasingly shows signs of experiencing a psychotic episode. The previous day, she had imagined herself perhaps having changed into a bearded man who was writing two tables away from her in the café; and then she loses her perception of time; she starts crying and then cannot distinguish from her tears and the rain pouring down the windows:

the "sudden great din outside [...] seems to be occurring right inside her as if her anger and confusion had emptied her and made a place in the middle of her chest for this great clashing of metal, or as if she herself had left this body and left it open to this noise, and then she wonders, Has the noise really come out into me, or has something in me gone out into the streets to make such a great noise. (Davis 2013, 113)

Davis' choice of the deictic this instead of that is coherent with the grammatical capacity of the former to not only anaphorically refer to what has already been mentioned (i.e. the finding of the clothes) but also to infer that there is something further to be said. This is explained in Lapaire and Rotgé's psycho-linguistic approach to grammar:

TH always interposes a psychic dimension between words and what they designate. It is the vibrant trace of the memory of operations. This marker acts like a psycho-grammatical relay (an "intermediary") between the

4 It is questionable that an abstract notion such as consternation be an agent, and the term causator is preferable with regards to twenty-first century English. However, in Buber's The Legend of the Baal-Shem we can find: "When the people who were in the room with us heard these words, consternation overcame them..." (Buber 2002, 116). 
WHEN GOING TOO FAR IS GOING JUST FAR ENOUGH:

APPROPRIATION, PARODY AND ADAPTATION IN LYDIA DAVIS'SHORT STORIES

referent (material or textual) and the expression which contains it. (Lapaire \& Rotgé 1991, 63 my translation)

Lapaire and Rotgé propose to break the deictic this and that up into their morphemes $\mathrm{TH}+\mathrm{IS}$ and $\mathrm{TH}+\mathrm{AT}$, with -IS congruent to nonclosure and -AT congruent to closure (Lapaire \& Rotgé, 63). Davis' choice of this corresponds to the fact that her version of the story is but a prelude to the real story which is that of the woman. Buber's choice of that is conducive to the closure necessary in a parable.

The addition of the coordinate conjunction but is also coherent. But can introduce two different types of opposition - corrective and argumentative; it can be interpreted three different ways: contrastive, concessive, or clearly pragmatic necessitating on the part of the reader to identify a clause that is missing. Pragmatic but has been shown to introduce ambiguity stemming partially from the fact that the clause the conjunction introduces, opposes, contrasts, argues with or is a concessive to, is not the clause present in the actual utterance, but rather one that is derived indirectly via various assumptions and inferences (Anscombre and Ducrot 1977, 1985, Rivara 1981, Lapaire \& Rotgé 1998, Huddleston \& Pullum 2002, Hetherington-Blin 2006).

This is the case with Davis' use of the conjunction here. Moreover, the use of BUT at the beginning of a sentence is called a commentary BUT. As Hoarau $(1997,110)$ points out, a conjunction at the head of an utterance is most often found in dialogues or in the most personalized parts of the narrative, as is the case here.

We speak of commentary BUT, because the propos in the coordinate clause is unexpected; it comes out of the blue, so to speak, and very often when BUT is used in this way, there is an implicit commentary (Sekali 2005, 17). The ambiguity stems from the fact that the reader must find the implicit clause which is being opposed in the sentence beginning with BUT. And as Sekali (2005) explains, the different types of ambiguity come from this need for the reader to identify this missing implicit clause.

In Davis' modification, we can imagine the commentary to be an implicit even so, which would be of a concessive value, but we can also imagine an implicit commentary leading to an opposition of much more argumentative value such as But, on the other hand,...

The identifying of the implicit clause in fiction is of great interest as it is often a means for a narrator to slip in another narrative voice (Hetherington-Blin 2006, 365). This can also be said of Davis' addition of AND at the beginning of "And he looked and looked" What Davis has 
done here is to surreptitiously slip in the narrative voice of her story instead of the more matter-of-fact one of the fable-telling Buber.

The blurring of the boundaries of the direct quote in the original, the introduction of the argumentative but with the added commentary effect, the commentary and blend to allow a coherence in narrative voice in her story as well as echoing the mental turmoil of her protagonist.

\section{"Marie Curie So Honorable Woman" - Parody and Vulnerability}

Appropriation takes on yet another dimension in her story "Marie Curie: So Honorable Woman" from her collection Samuel Johnson is Indignant. The story is a parody of Francoise Giroud's Marie Curie: Une Femme Honorable, which Davis translated but did not enjoy. In an interview with the Financial Times she says that Giroud's sentences were so sentimental and nonsensical that "they were too good to waste" (Strokes 2010).

The story is divided up into 45 sections, with Davis choosing only the most sentimental moments in Giroud's book. She translates them using unidiomatic phrases, with many of the sentences translated literally from the French even to the point of respecting the French syntax. For example, here is the section recounting the death of Pierre Curie:

The body is removed to a police station. An officer picks up his telephone. But Pierre Curie no longer has ears to be annoyed that he belongs, in death as in life, to the number of those for whom one disturbs the Minister of the Interior. (Davis 2013, 407)

As Evans explains, it fits the literary and legal definition of a parody in that the awkward translation provides the critical distance that is necessary for a parody". Evans argues that "Marie Curie: So Honorable

\footnotetext{
The classification of this story as parody poses a problem in that for it to be legally considered so, the work must be viewed as a form of criticism of the original work (Evans, 124). But for a work to unequivocally stand as parody the source text must be accessible/recognizable to the reader. As Evans states, this is not the case for "Marie Curie So Honorable Woman" and while the parodic intent is clear through Davis' use of nonstandard, uncolloquial English, Evans prefers to classify it as an appropriation. Evans explains: "Appropriations, according to Sanders (2006, 26 in Evans, 124), do not always explicitly acknowledge their sources. She argues that appropriations in literature often
} 
WHEN GOING TOO FAR IS GOING JUST FAR ENOUGH:

APPROPRIATION, PARODY AND ADAPTATION IN LYDIA DAVIS'SHORT STORIES

Woman" questions the possibility of fair representation by highlighting how representation is always the result of interpretation and so always selective (Evans, 124).

There is another interesting aspect here. In her parodying of Giroud's text, she is also parodying literal translation. One of the criticisms that Davis' translations often receive is that in staying so close to the syntax of Flaubert, the result is a certain dryness of style. In his criticism of Davis in the London Review of Books, Barnes writes:

Davis's Madame Bovary is a linguistically careful version, in the modern style, rendered into an unobtrusively American English. At its best, it conveys the precision - which some think dryness - of Flaubert's prose in this novel, while its syntactical mirroring of the French sometimes brings us closer to Flaubert. At its worst, it takes us too far away from English, and makes us less aware of Flaubert's prose than of Davis being aware of Flaubert's prose. And such defects come from something very oldfashioned: a lack of love for the work being translated. (Barnes, 2010)

The story can be interpreted as a tongue-in-cheek commentary on what happens when a translator does indeed stick too closely to the text. However, there are two interesting and unexpected results of this parody of Giroud's story. In her interview with Strokes of the Financial Times, Davis says that she was interested "in the idea that a story written very badly could also be very moving". In "Marie Curie So Honorable Woman", we have an example of what could be considered a form of what Evelyn Ch'ien (2004) has called the "weirding of English".

The weirding of English is what happens when authors permit their characters with an immigrant background to express themselves in unidiomatic English where much of the dialect of the mother tongue is incorporated in the syntax, in the vocabulary and in the native identity of the character thus allowing their belonging in and to a community to be left intact. Obviously, what Davis is doing here is not the same. Her motivation is a to write a parody - the effect being first and foremost humorous. But it can be considered a form of weirding in that just as in the works of Junot Diaz, or Amy Tan whose characters are strangely

stem from a 'political or ethical commitment on the part of their creator" (Sanders, 2 in Evans, 124). Evans specifies: "Davis' story questions the reader's understanding and expectations in relation to (1) representation, (2) translation, (3) parody, (4) the use of intertextuality, (5) the correct use of the English language, among other things" (Evans, 125). 
moving, "Marie Curie So Honorable Woman" moves us because the vulnerability of these characters is conveyed so clearly because of the faulty expression ${ }^{6}$.

Even badly translated and written in the form of a synopsis, Marie Curie's story holds our attention because Davis chooses not only the parody of a work, but includes with this a parody of translation, and writes the story in the form of a resumé. It is the three together that make us pay special attention to the mystery of language. In her choice of language Davis allows the reader to share the translator's relationship to language we are like Barthes "seeing language" (Barthes 2002, 735)

\section{Flaubert c'est moi}

In the 14 stories from Flaubert, Davis takes appropriation to new heights. Evans speaks of "dual authorship" (Evans, 106). Other than resurrecting nineteenth-century Flaubert into a twenty-first century short story collection, Davis makes the translator disappear in this collection. It is the nature of this duality that interests me. Careful inspection which can be carried out only by the bilingual reader, staying very closely to the text, reveals that she has done much more than she suggests in her afterward.

A first hasty reading through Flaubert's letters comparing them to the stories does not enable the reader to fully grasp the extent to which Davis has made Flaubert's letters her own. In Blin (2017, 46-48) I already analyzed what I considered to be choices of Davis the translator in two of the stories, "The Cook's Lesson" and “The Exhibition". But when trying to pinpoint more closely how she went about adapting these extracts from letters, it became obvious that parts of these stories had been entirely made up by Davis.

For example, in "The Chairs" (Davis 2015, 113), it turns out the material used in this story does not appear in any of the letters written in 1853-1854.

6 Ch'ien explains: "Though weird English writers may be fluent, they can still tap into the activity of learning a language. They resemble philosophers who converse with facility in English but still view themselves as being in the process of learning the language of rhetoric and investigation" (Ch'ien, 23). This is not exactly the case of Davis, but there is no doubt that as a translator and a writer she is constantly investigating the intricacies of language. 
WHEN GOING TOO FAR IS GOING JUST FAR ENOUGH:

APPROPRIATION, PARODY AND ADAPTATION IN LYDIA DAVIS'SHORT STORIES

In Davis' adaptation, the narrator tells of his friend Louis going to the church in Nantes. "He wants to learn as much about people as he can by looking at their chairs" (113). He starts with a woman he calls Madame Fricotte. Though the family name, Fricotte, exists in France, for the bilingual reader there is an obvious double-entendre, as the verb fricoter also means "to flirt". For the Madame Bovary reader, one might read it as a tongue-in-cheek humorous reference by Flaubert to Emma, for whom flirting became the source of the novel's tragic theme. But when we discover that it is Davis herself who wrote this story, the paratext "story from Flaubert", which accompanies each of titles, takes on a new dimension. Other than the obvious "Flaubert, c'est moi", Davis has more than blurred the line between translator and author, she has here usurped the style of the Flaubertian sentence and made it her own thus leading us to re-consider the preposition "from".

From is a movement preposition. It expresses not only the idea of distancing, but also it includes the source point from where the distancing takes place. In Davis' titles she systematically includes "story from Flaubert" as a subtitle to each of her stories. But in "The Chairs", there is no source text, only source style. What becomes increasingly clear is that the reader who has taken the preposition from as a synonym for by has been clearly mistaken.

The term "adaptation" normally applies to a film, a play, or a book that has been made from another film, play or book (Cambridge Dictionary). Here, as in all these "stories from Flaubert" Davis has adapted the Flaubertian style into a short story. Davis has said in many interviews that one of the aspects she enjoys the most about translating is adopting another voice, another culture, another way of writing, but with these stories "from Flaubert", she has underlined the link between translation and adaptation.

In another story, "The Exhibition", Flaubert pays a few pennies to see some savages on display:

\section{The Exhibition}

Yesterday, in the deep snow, I went to an exhibition of savages that had come here from Le Havre, The poor Negroes, and their manager too, looked as if they were dying of hunger. (Davis 2015, 134) 
The twentieth-century concept of political correctness was of course not a concern to Flaubert. We can assume that the 164-year distance that marks Davis' publication as well as the "story from Flaubert" paratext alleviates any controversy the use of the word "Negroes" has today (Blin 2017, 45-46). However, a closer examination of the letter from which this story is adapted from reveals that the word "Negroes" was not, in fact, in the original text. It is Davis herself who added it.

Why would Davis have to add the word, if it was only to draw our attention to the debate on political correctness? Flaubert's own description in the French text would have amply sufficed. Here is another excerpt from the story in Davis' translation:

We waited for some time. Then a sort of wild beast appeared wearing a tiger skin on his back and uttering harsh cries. A few more followed him into the room - there were four altogether. They got up on a platform and crouched around a stew pot. Hideous and splendid at the same time, they were covered with amulets and tattoos, as thin as skeletons, their skin the color of my well-seasoned old pipe, their faces were flat, their teeth were white, their eyes large, their expressions desperately sad, astonished and brutalized. [...] I felt as though I were seeing the first men on earth - as though they had just come into existence and were creeping about with the toads and the crocodiles. (Davis 2015, 134)

Davis has slightly softened Flaubert's description, and added the word "Negroes". Here is the passage in French, which Davis adapted. Bold print signals the more questionable passages:

Après quoi une espèce de bête fauve, portant une peau de tigre sur le dos et poussant des cris inarticulés, a paru, puis d'autres. Ils sont montés sur leur estrade et se sont accroupis comme des singes autour d'un pot de braise. Hideux, splendides, couverts d'amulettes, de tatouages, maigres comme des squelettes, couleur de vieilles pipes culottées, face aplatie, dents blanches, œil démesuré, regards éperdus de tristesse, d'étonnement, d'abrutissement, ils étaient quatre et ils grouillaient autour de ces charbons allumés, comme une nichée de lapins. (Flaubert 2003)

The comparison with monkeys and rabbits is shocking enough, and if it were this aspect of Flaubert she wished to convey, why choose not to include these passages rather than add Negroes instead? Davis also added an entire paragraph to the story, but we can conclude that that addition corresponds to what Davis explained in the acknowledgments about creating a balanced story. But Davis makes another surprising addition to another Flaubert letter - an entire scatological paragraph in the story "Staying at the Pharmacist's" (Davis 2015, 243-244). Choosing to 
WHEN GOING TOO FAR IS GOING JUST FAR ENOUGH:

APPROPRIATION, PARODY AND ADAPTATION IN LYDIA DAVIS'SHORT STORIES

translate the French word "court" by "shithouse", she adds the following paragraph:

The pharmacist's latrine is so small and dark that you have to leave the door open when you crap, and you can hardly move your elbows to wipe your ass. The family dining room is right there, close by. You hear the sound of turds falling into the can. (Davis 2015, 244)

This is a distancing of a different sort, as Davis makes no attempt to choose a vocabulary that would be closer to Flaubert's nineteenth-century one. As this is so foreign to Davis' method of translating, even though this particular passage is not one, it draws our attention to the act of translation itself.

My tentative response to Davis' usurping of Flaubert's style is that she wishes to concretize the link between adaptation and translation. The scatological addition and the addition of the word Negroes is perhaps a tongue-in-cheek reflection on political correctness. We might note that, whereas the scatological entries are not so likely to shock a twenty-first century readership, the designation of African peoples as "savages" and "negroes" surely would.

In a 2014 interview with Gunn, Davis explains the essential difference between translating a work, where she is bound by the translator's code of ethics, and the liberty she experiences when adapting:

There is certainly much less anxiety for me converting the "found" material in Flaubert's letters into self contained stories, even though the conversion is more radical than any straight translation would be. [...] In straight translations, I feel bound by a contract - not on paper, but one that exists in my own code of ethics of translation to reproduce as closely and faithfully as I can the work as the author wrote it, complete with mistakes (there are a couple in Proust for instance). Whereas, when I happened upon little stories in Flaubert's letters it was like discovering some precious metal in the earth, which I could then shape into something with a form that I would determine. But the material was already there, with its limits or boundaries - this is what I had to work with. (Gunn, 2014)

\section{Conclusion}

In each of these adaptations, Davis' stories are a constant invitation to the reader to pay attention to language, down to the very coordinate conjunction as in "Once A Very Stupid Man", or to a prefix, such as in the 
word extraordinary, or to the preposition from in her "stories from Flaubert".

Davis recounts how she was hesitant about translating Madame Bovary because she had not liked the novel when she had read it in English as a teenager. She tells of changing her mind, when she read it in French where she discovered Flaubert's irony, the power of the Flaubertian sentence, and just how modern he was. Davis did not consult the other 19 translations before drawing up her first draft, but she did before revising. She notes that the translators had for the most part, translated according to their own particular manner, whereas she aimed to remain faithful to Flaubert's own style, sticking to the syntax as closely as possible, and incorporating nineteenth-century English for the vocabulary (Davis 2011). Davis has managed to integrate Flaubert's style so intimately that her additions go unnoticed. She explains it herself:

There is a wonderful way in which the writer - or a translator - can be effaced by the reality or a stronger presence. The writer after all, is the scribe, the witness, and has to step back before the others. [...] If you're a translator you have to become the other person, the other writer, if you're going to be any good. You have to speak in the voice of the other person. You can't speak in your own voice, you can't have one consistent voice that you stamp on everything you translate. (Knight 1999, 536)

Davis has so thoroughly become a ventriloquist of Flaubert that we do not even see her lips moving. 


\section{BIBLIOGRAPHIE}

ANSCOMBRE, Jean-Claude \& DUCROT, Oswald. 1977. "Deux mais en français ?" Lingua $43: 23-40$.

ANSCOMBRE, Jean-Claude \& DUCROT, Oswald. 1985. L'argumentation dans la langue. Bruxelles: Pierre Mardar.

BARNES, Julian. 2011. "Writer's writer and writer's writer's writer." London Review of Books: 8-11.

BARTHES, Roland. 2002. Roland Barthes par Roland Barthes. In E. MARTY (ed.), Oeuvres Complètes IV. Paris: Seuil.

BLIN, Lynn. 2017. "Negotiating loss and the voice of the translator in Lydia Davis' Can't and Won't. " Etudes de Stylistique Anglaise 11: 38-56.

BUBER, Martin. 2002 [1948]. The Way of Man. London: Routledge.

BUBER, Martin. 2015 [1948]. The Way of Man According to the Teachings of Hassidism. May 2015. http://combunianum.org/, accessed 04 July 2018.

BUBER, Martin. 2002 [1908/1955]. The Legend of the Baal-Sham. London: Routledge.

CH'IEN, Evelyn Nien-Ming. 2004. Weird English. Cambridge: Harvard University Press.

DAVIS, Lydia. 2007. Varieties of Disturbance. New York: Farrar Strauss and Giroux.

DAVIS, Lydia. 2013 [2009]. The Collected Stories of Lydia Davis. London: Penguin Books. 
DAVIS, Lydia. 2010. "Ten Stories from Flaubert"

https://www.theparisreview.org/fiction/6038/ten-stories-from-flaubertlydia-davis, accessed 23 june 2018.

DAVIS, Lydia. 2011. "Some notes on translation and on Madame Bovary." Paris Review. https://www.theparisreview.org/lettersessays/6109/some-notes-on-translation-and-on-imadame-bovary-ilydia-davis, accessed 14 September 2018.

DAVIS, Lydia. 2015. Can't and Won't. St Ives: Penguin Random House.

EVANS, Jonathan. 2017. The Many Voices of Lydia Davis: Translating, Rewriting, Intertextuality. Edinburgh: Edinburgh Scholarship online.

FLAUBERT, Gustave. 2003. Correspondance 1853. "Flaubert Université de Rouen." Flaubert Université de Rouen ed. Danièle Girard \& Yvan Leclerc. <flaubert.univrouen.fr/correspondance/conard/outils/1853.htm $>$, accessed 17 November 2017.

FLAUBERT, Gustave. 2003. Correspondance 1854. "Flaubert Université de Rouen." Flaubert Université de Rouen. (eds.) Danièle Girard \& Yvan Leclerc. <flaubert.univrouen.fr/correspondance/conard/outils/1853.htm $>$, accessed 17 November 2017.

GUNN, Dan. March 102014 The Quarterly Conversation - the Lydia Davis Interview. http://quarterlyconversation.com/the-lydia-davisinterview, accessed 4 July 2018.

HETHERINGTON-BLIN, Lynn. 2006. L'ambiguité des liens: la coordination en anglais. Aix-en Provence. Ph.D.thesis under the direction of Francoise Dubois-Charlier.

HOARAU, Lucie. 1997. Linguistique contrastive et traduction: étude contrastive de la coordination en francais et en anglais. Paris: Ophrys. 
WHEN GOING TOO FAR IS GOING JUST FAR ENOUGH:

APPROPRIATION, PARODY AND ADAPTATION IN LYDIA DAVIS'SHORT STORIES

HUDDLESTON, Rodney \& PULLUM, Geoffrey. 2002. The Cambridge Grammar of the English Language. Cambridge: Cambridge University Press.

KNIGHT, Christopher. 1999. "An interview with Lydia Davis." Contemporary Literature 40.4: 525-551.

LAPAIRE, Jean-Rémi and ROTGE, Wilfrid. 1991. Linguistique et Grammaire de l'Anglais. Toulouse : Presses Universitaire du Mirail.

MCCAFFERY, Larry. 1996. Some Other Frequency: Some Interviews with Innovative American Authors. Philadelphia: University of Pennsylvania Press.

RICKS, Christopher. 2013. "The Art of Lydia Davis". In Lydia DAVIS, The Collected Stories of Lydia Davis. London: Penguin, p. xii-xxii.

RIVARA, René. 1981. "Mais, le but anglais et les subordonnés de concession." Sigma 6 45-56.

SANDERS, Julie. 2006. Adaptation and Appropriation. Abingdon: Routledge.

SEKALI, Martine. 2007 [2005]. "Pour une analyse énonciative des phénomenes pragmatiques: le cas du coordonnant BUT anglais." In A. CELlE \& R. HUART (eds.), Connectives as Discourse Landmarks, Pragmatics \& Beyond New Series, 161. Amsterdam: John Benjamins Publishing Company, p. 155-175.

STROKES, Emily. 2018. Financial Times 1 August 2010. https://www.ft.com/content/5c1059dc-a0ea-11df-badd00144feabdc0, accessed June 28, 2018. 